\title{
Development of Synthetic Variety of Coconut: PCA Syn Var 001 I. Status and Prospects
}

\author{
Ramon L. Rivera, $\mathrm{MSc}^{1}$, Gerardo A. Santos ${ }^{2}$, Susan M. Rivera, $\mathrm{PhD}^{3}$, \\ Ernesto. E. Emmanuel, $\mathrm{MSc}^{4}$ and Gerardo. B. Baylon ${ }^{5}$
}

\begin{abstract}
Increased genotypic heterozygozity through phenotypic disassortative mating improves vigor and yield performance of progenies, while inbreeding causes depression, thus the use of $F_{2}$ seeds from $F_{1}$ variety hybrids could lead to disastrous results. Knowing the partiality of coconut farmers in using seeds from any high yielding variety for successive cropping, the development of an openpollinated variety or OPV with a high degree of balanced heterozygozity is highly desired.

Started way back in 1979, the PCA pioneered the development of a synthetic coconut variety, i.e., PCA SYN VAR 001. With some modifications of the classical breeding method, a scheme was formulated to produce the base population of a synthetic coconut variety using single crosses from six tall coconut cultivars, four local and two foreign tall varieties, which were found to possess good general combining ability (GCA). Field planting of the $F_{1}$ base populations was done in September 1992. Since then, observations on growth and development, flowering and early yield of the genetic materials, as well as the distributions of "bulked" seeds from the plantation are ongoing. The use of modern molecular marker tools, i.e. microsatellite or Simple Sequence Repeat (SSR) marker technology in the development of the synthetic variety of coconut, including the status of the research undertakings and prospects of the new breeding populations are described in this paper.
\end{abstract}

Keywords: Coconut, synthetic variety, composite variety, open-pollinated variety.

\footnotetext{
${ }^{1}$ Division Chief III, Breeding and Genetics Division, PCA-ZRC

${ }^{2}$ Department Manager III (retired), PCA-ZRC

${ }^{3}$ Sr. Science Research Specialist, Breeding and Genetics Division, PCA-ZRC

${ }^{4}$ Science Research Specialist II, Breeding and Genetics Division, PCA-ZRC

${ }^{5}$ Officer-In-Charge, PCA-ZRC

Philippine Coconut Authority-Zamboanga Research Center (PCA-ZRC), San Ramon 7000, Zamboanga City

Telefax Number:+63 629820302

Emails: pca-zrc@pldtdsl.net, rlrivera_pca@yahoo.com.ph,smrivera@yahoo.com,emmanuelbgd@yahoo.com
} 


\section{Introduction}

Compared to the late maturing and loweryielding commercial tall varieties, dwarf $\mathrm{x}$ tall coconut variety hybrids $(\mathrm{d} x \mathrm{t})$ have gained popularity as planting or replanting materials on account of earlier maturity, high and stable yield, uniformity and ability to recover quickly from environmental stresses. However, due to the influence of the dwarf parent, $\mathrm{F}_{1}$ hybrids from $\mathrm{d} \mathrm{x}$ $t$ crosses have a life span that could be shorter than the traditional tall varieties. In addition, in view of the high costs involved in maintaining isolated seed gardens, only a few large-scale plantation owners can afford to replant with coconut hybrids on their own. It has been long recognized that for the Philippine coconut industry to prosper, government assistance must be focused to the majority of smallholders, which make up the backbone of the coconut industry. Thus, development programs to revitalize the coconut industry like the just concluded Small Coconut Farms Development Project (SCFDP) of the Philippine Coconut Authority (PCA) are based on the use of hybrids as the medium term goal.

The current estimated cost of coconut hybrid seed is about $\mathrm{PhP} 33.00$ per piece $(40 \mathrm{PhP}=1$ USD), PhP 25.00 of the cost of nut and PhP 8.00 for freight). Most of the cost of the seednut goes to labor $(\sim 65 \%)$ and the rest to the various supplies needed in hybrid production. In contrast, the farm gate price of an open-pollinated variety (OPV) seednut is only around $\mathrm{PhP} 8.00$. As the initial cost of seednut distribution would involve the shipment of the foundation seeds, the cost of seednut transport would likewise be very minimal for OPV seednut production.

Similar to other commodity crops where a change in variety results in dramatic increase in yield, which subsequently spurs a wider adoption of the variety by more farmers, PCA's long term varietal improvement program includes the development of early maturing and high yielding OPVs that would support a sustainable replanting program - because more seeds would be readily available at a cheaper cost. Moreover, it would suit the generally accepted bias of farmers for a variety with bigger and heavier nuts; consistent with the traditionally accepted prejudice of coconut farmers of using seeds from high yielding palms for the second cropping.

This long-term project was started 25 years ago at the PCA Zamboanga Research Center at San Ramon, Zamboanga City. Since then, observations on growth and development, flowering and early yield, floral biology and pollen dispersal were made. Also, the application of molecular marker technology for coconut research provides a robust and precise tool in assessing the genetic structure of the synthetic variety base populations and in evaluating the breeding value of the succeeding generations. This report describes some of these.

\section{Rationale}

The continuing search for improved coconut planting materials is being done through mass selection and hybridization methods. However, other methods of producing these improved materials are available and should be explored. The possibility of developing an open pollinated variety through the synthetic variety approach is a very promising alternative since this could provide farmers the opportunity to produce their own seeds.

A synthetic variety of coconut has many advantages. First, mass propagation of seeds in synthetic varieties is based on open pollination. Second, synthetic varieties are more flexible in terms of environmental adaptation and variable market requirements due to their wider magnitude of genetic structure compared to hybrids and double crosses. Third, in terms of genetic conservation, synthetic varieties can "freeze" certain characters, which may be lost due to small population size in restructuring of gene pools.

Considered as a first of its kind in the country and recently recognized as the first in the world, the project maybe regarded as the Philippine Coconut Authority's ultimate strategy 
in the mass propagation of improved planting materials for the national coconut planting and replanting program.

\section{State of the Art}

\section{Coconut Breeding Objectives}

Since the beginning, coconut breeders around the world relied solely on the classical approach in varietal improvement but nonetheless obtained important, albeit limited results. The PCA's breeding objectives for high yield of copra and oil combined with early flowering, tolerance to most diseases; water stress and wide adaptability remained basically the same from 1972 up to now (Santos, 2004).

To improve copra and oil yield genetically, most coconut breeders followed four basic methods, namely mass selection, progeny testing, recurrent selection, and hybridization. Depending on the available genetic resources and the "breeder's nose", the combination of mass and recurrent selection followed by hybridization produced immediate practical results. This led to the creation of high yielding hybrids now used in many countries (Rattanapruk et al., 1984; Novarianto, 1987; Rompas, 1988; Meunier, 1992; de Nuce de Lamothe and Benard, 1995; Luntungan, 1997; and Santos et al 1979).

In 1976, Baliñgasa and Carpio discovered the genetic potential of several local populations. This paved the way for the recommendation of the four tall and two dwarf coconut populations as promising planting materials. They identified tall (Tagnanan, Laguna, Baybay, Bago Oshiro) and dwarf (Tacunan and Catigan) populations as promising varieties that can be used by farmers for planting and/or replanting. Gemperle and Fremond (1978) reported the promising potential of the Tagnanan tall and from then on, significant attention was focused in this important local tall from the Philippines in many coconut-breeding programs in the world. Among the most famous of the hybrids thus created from the Tagnanan tall are the PCA 15-2 (MRD x TAGT), PCA 15-4 (CATD $x$ TAGT) and PCA 15-9 (TACD $x$
TAGT) of PCA and the MATAG hybrid in Malaysia.

It is obvious that, as defined by Fremond and co workers (1966) and Bourdeix (1988), mass selection for traits having high heritability such as number of nuts, copra weight per nut and total copra per palm increased the average yield of the selected populations in the succeeding generations. Selection of palms having nuts with good fruit composition has also improved the fruit characters of the succeeding generations (Santos and Sangare, 1992). This is considered necessary since majority of the small farmers who produce the bulk of the coconut products that are traded in the world market, prefer varieties bearing medium to large nuts and do not require much fertilizers (Novarianto and Santos, 1996).

\section{Coconut Synthetic Variety}

The theoretical basis of the Syn Var experiment that was pioneered by PCA breeders in 1979 relied on the assessment of genotypic value of parental materials through the measurement of morphometric traits of different phenotypes. It worked relatively well in past experiments leading to the coconut hybrids of today. However, the technique is tedious and also error-prone. Its importance has somehow become outdated and can be tremendously improved if done together with current modern techniques of evaluation.

Like most cross-pollinated crops, increased genotypic heterozygozity leads to heterosis in coconut. Phenotypic disassortative mating or mating of unlikes promotes it. In contrast, even one cycle of self-pollination immediately leads to inbreeding depression (Satyabalan and Laksmanachar, 1960). Although the use of $F_{2}$ seeds from $\mathrm{a} \quad \mathrm{d} \quad \mathrm{x} \quad \mathrm{t} \quad \mathrm{F}_{1}$ hybrid is not recommended, farmers' bias has brought about a unique situation in a coconut farm because no amount of explanation could prevent most coconut farmers from using seeds of any high yielding variety for a second crop (Terminal Report PCA/PCARRD Multiloc Project, 1996). 
The fundamental aim therefore is to produce a population of palms having a high degree of balanced heterozygozity as earlier suggested by Banzon and Velasco (1982) and to develop a breeding scheme that would allow these individuals to mate at random to maintain the high degree of heterozygozity and heterosis from generation to generation.

There are two ways of doing this. The first is the age-old method of mass selection (MS) and the other one, the development of a synthetic variety (SYN). Mass selection in coconut is a good alternative but it has several disadvantages. These are associated to the loss of vigor in succeeding generations due to inbreeding and limited genetic advance considering that selection is based solely on the phenotypic traits of the female parents.

On the other hand, the purposeful creation of a SYN could lead to more permanent genetic gains over many generations and could achieve greater adaptability and stability in performance due to wide genetic base. Likewise, seeds of SYN are produced under natural conditions and constantly exposed to natural selection. Most importantly, farmers may use the SYN seeds directly for a second crop and expect better yields in the process. Over the long term, it could sustain immense commercial hectarage over time and even in places where areas are too small to support a hybrid industry.

Notwithstanding these advantages, a synthetic variety is difficult to breed because it would take more than 30 years to come up with a population of palms having the traits of the parents used in the breeding program. Its yield may not surpass that of the best single crosses and once introduced, there could be a dilution of its genetic make up under farmers' farming conditions. Due to pan mixia, the genotypic compositions of successive SYN populations would vary from one another.

\section{Objectives}

1. To develop and produce the first synthetic coconut variety in the Philippines and in the world;

2. To test its performance and adaptability over a wide range of growing conditions and evaluate its genetic potential;

3. To utilize its possible advantages such as higher yield potential, wider adaptability and ease of seed production;

4. To make use of the coconut synthetic variety to establish provincial seedfarms, which could serve as sources of high yielding planting materials, and ultimately provide an alternative and more sustainable strategy in the mass propagation of improved planting materials for the coconut planting and replanting program of the country.

\section{Materials and Methods}

To maximize heterozygozity and heterosis, six well-studied tall coconut varieties namely, Baybay (BAYT), Rennel (RIT), Bago Oshiro (BAOT), Laguna (LAGT), West African (WAT) and Tagnanan (TAGT), were used in the breeding program (Baliñgasa and Carpio 1976; Chan 1978; Gemperle and Fremond 1978; Mendoza and Baliñgasa, 1978; and De Nuce de Lamothe and Wuidart 1980). These were chosen on the merits of: good general combining ability (GCA); cross-pollinating habit; genetic potential; and distinctness, uniformity and stability (DUS).

Growing conditions. Zamboanga Research Center is located in an intermediate growing zone with an elevation of 3-6 meters (above sea level). The average annual rainfall is around $1,600 \mathrm{~mm}$ with $80-90$ rainy days. The driest months are from December to May wherein low to high water deficits are normally encountered. The soil in the area belongs to the silty clay loam type, relatively deep and very well drained. The block where the SYN VAR 
experiment was planted is located between two rivers, the Talisayan on the South and the Saaz on the North. Since the water from the Talisayan River was diverted for an irrigation project in the mid 1970s, it only gets spilled water during the rainy season. On the other hand, the San Ramon Saaz River only went dry during the El Niño phenomena in 1983 and 1998.

Production of selfed lines. As it is impossible to conduct a series of self-pollinations to obtain pure inbred lines in annual crops within a lifetime, only one cycle of self-pollination was conducted for the varieties LAGT and BAOT. The other four varieties, i.e. BAYT, TAGT, WAT and RIT were no longer selfed but they were selected for general uniformity.

Production of single crosses. Following a modified scheme for the development of a synthetic variety (Chart 1), 3,000 t x t $F_{1}$ variety hybrid progenies from 15 crosses were artificially bred. Successive hand pollination of 5 to 6 inflorescences per palm to produce 200 nuts per cross in a diallele fashion minus the reciprocals were done (except for three crosses, i.e. BAOT $x$ RIT, BAOT $x$ WAT and LAGT $x$ WAT). This was important because the size of the experimental field would have become exceedingly large, i.e. 30 hectares, and the number of plants to maintain will be too big to handle. In the production of $\mathrm{F}_{1} \mathrm{t} \times \mathrm{t}$ crosses, 26 parental palms represented each variety. The technique of controlled hand pollination of coconut as described by Baliñgasa and Santos (1978) was used to ensure the legitimacy of the hybrids.
Care and maintenance of seedlings. The seednuts were sown and germinated in seedbeds and grown in a standard polybag nursery following routine maintenance activities until the seedlings reached the age of 10 to 12 months from the date of germination. Very minimal selection was practiced in the nursery and only normal and healthy seedlings were chosen at planting time. Field planting was done on August and September 1992 in an isolated field having a contiguous area of about 13.6 hectares (Figure 1).

Planting layout. The seedlings were planted at a distance of 8.5 meters or at a density of 160 palms per ha following the triangular system of planting. Each seedling was given a permanent label and planted following a randomized field-numbering scheme to ensure maximum pan mixia at maturity. It was assumed that each of them would have equal chances of mating with one another to produce the $F_{2}$ population(s) or $S_{y_{1}}$ at flowering time. Figure 2 shows a sample of the triangular layout of the $\mathrm{F}_{1 \mathrm{~S}}$ or $\mathrm{Syn}_{0}$.

Field upkeep and data gathering. Field upkeep and maintenance included cover cropping, regular application of fertilizers, weed control, regular indexing and control of pest and diseases. The various $\mathrm{F}_{1}$ hybrid lines are being evaluated for vegetative as well as reproductive growth and development. The palms were periodically observed for leaf production, flowering distribution and nut yield. Observations on floral biology (12 palms

\section{Chart 1. Scheme for the Development of the Synthetic Variety (Syn Var)}


Cord 2008, 24 (1)

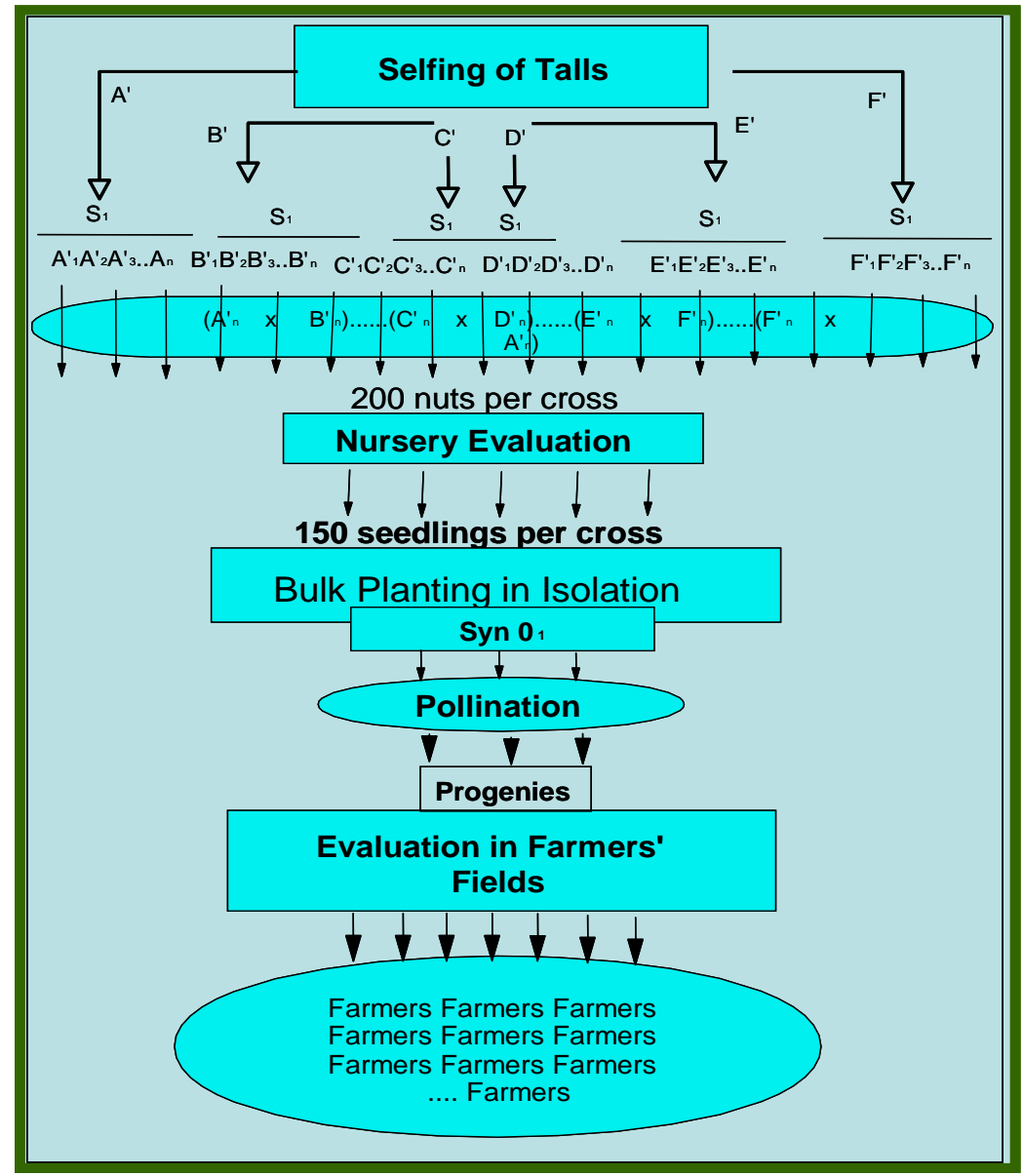

Figure 1. Field Layout of Synvar experiment

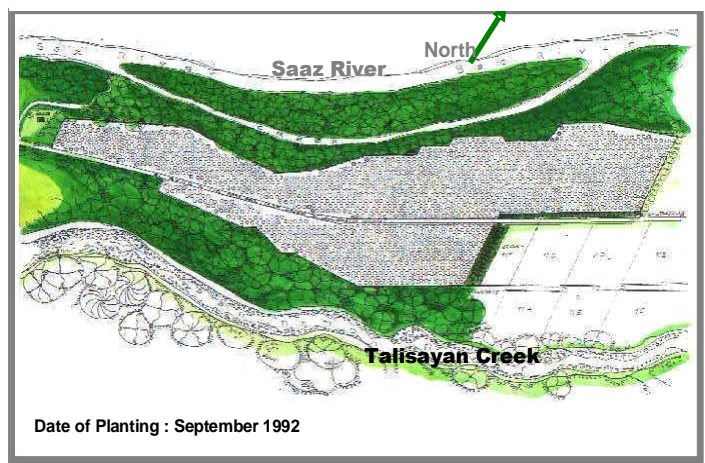

per cross) and pollen dispersal using petroleum jelly traps were also conducted at different locations within the experimental SYN VAR block. To lessen the expenses for weeding, cattle were allowed to intermittently graze along the
Figure 2. Triangular system of planting

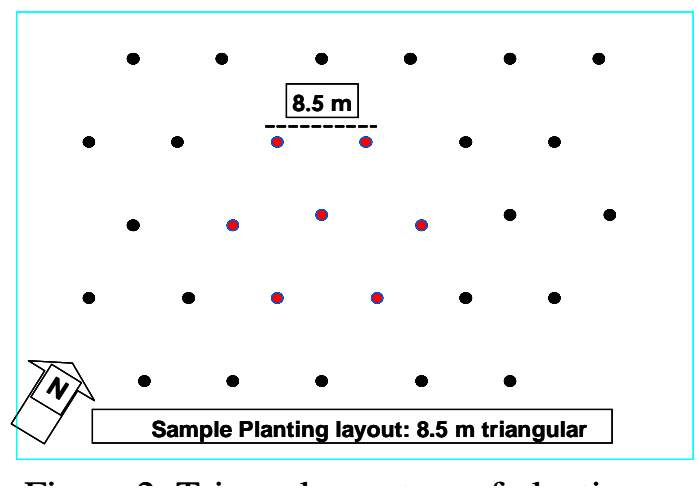

inter rows when the palms reached five years old. Regular harvesting of nuts was done when the palms reached the reproductive stage. Fruit component analysis (FCA) was started when 95\% of the palms reached full maturity. The 
general procedures are well described in the Stantech Manual (Santos et al 1996).

Seed production. As soon as the palms come into flowering, inter pollination will be done to produce $\operatorname{Syn}_{1}$ (first generation synthetic). If the resources permit, during the first few years, progenies will be field evaluated in isolation and compared with one another. The highest and most stable yielding progenies will be selected for mass propagation.

The inter-crossed or open-pollinated nuts from $\operatorname{Syn}_{1}$ constitute the second generation $\left(\mathrm{F}_{3}\right.$ synthetics or $\mathrm{Syn}_{2}$ ). Theoretically, the $\mathrm{F}_{3}$ presents the value of the synthetic variety and no considerable loss in vigor is expected onwards. It can therefore be released to farmers for trial planting.

Use of molecular marker technology, i.e. microsatellite (SSR) marker technique. Molecular marker technology, in particular the SSR marker technology on coconut, have made significant impact on the methods of assessment of the genetic structure of populations as well as in locating desirable genes in breeding materials (Rivera et al., 1999) and will be utilized in assessing the genetic structure of the SYN VAR populations as well as in accelerating the identification of heterozygous individuals possessing desirable traits even as early as the seedling stage. The SSR protocol in combination with available molecular marker techniques in coconut as existing resources permit will be utilized in the important phases of the conventional breeding protocol in the development of coconut OPVs. Once made available, the use of identified linked markers that could facilitate selection and getting desired genotypes at higher probability will likewise be explored. These research directions certainly

Table 1. Field planting and flowering status of Syn Var 001 entries as of March 2000 (90 months from field planting)

\begin{tabular}{|c|c|c|c|c|c|c|c|c|}
\hline \multirow{2}{*}{ No } & \multirow{2}{*}{ Cross } & \multicolumn{2}{|c|}{ Original } & \multicolumn{2}{|c|}{ Existing } & \multirow{2}{*}{$\begin{array}{l}\text { Survival } \\
\text { Rate (\%) }\end{array}$} & \multicolumn{2}{|c|}{ Flowering } \\
\hline & & (no) & $(\%)^{1}$ & (no) & $(\%)^{2}$ & & (no) & $(\%)^{3}$ \\
\hline 1 & BAOT x BAYT & 92 & 5 & 77 & 5 & 84 & 75 & 97 \\
\hline 2 & BAOT $x$ RIT \& RIT $x$ BAOT & 142 & 8 & 119 & 7 & 84 & 118 & 99 \\
\hline 3 & BAOT x TAGT & 105 & 6 & 89 & 5 & 85 & 85 & 96 \\
\hline
\end{tabular}

pave the way for breeders to optimize coconut genetic improvement methods and research technology outputs.

\section{Results and Discussion}

The primary aim of the project is to create an "open- or cross-pollinating population of highly heterozygous individual palms" possessing the qualities of the six good combining tall varieties. As a first step in the process of evaluation, observations on the growth and development and early yield patterns of the parental hybrids were recorded. These are needed to ensure the "balanced bulking" of progenies from the most productive individuals when the palms reach at least $95 \%$ productivity. Initial observations reveal a very interesting trend presented elsewhere in this paper.

Survival rate. Although the original plan was to plant equal number of palms per entry to allow equal male and female gametes distribution among all plants at flowering time, it was not fully realized as shown in Table 1. The onset of the El Niño phenomenon in 1998 somehow affected the palms to natural selection at its best. This aspect is critical because it would determine the sampling rate that would be used for the next SYN generations. For instance, among the entries, five hybrids showed survival rates lower than $90 \%$ percent. The lowest number of palms i.e. BAOT $x$ BAYT, with 75 palms would therefore be the basis for the next SYN generation $\left(\operatorname{Syn}_{1}\right)$.

Leaf production and girth size. At the age of seven years after field-planting, evaluation of growth and development showed comparable rates of leaf production among all 


\begin{tabular}{|c|c|c|c|c|c|c|c|c|}
\hline 4 & BAOT x WAT \& WAT x BAOT & 118 & 7 & 119 & 7 & 101 & 117 & 98 \\
\hline 5 & BAYT x TAGT & 138 & 8 & 127 & 8 & 92 & 115 & 91 \\
\hline 6 & LAGT x BAOT & 108 & 6 & 105 & 6 & 97 & 96 & 91 \\
\hline 7 & LAGT x BAYT & 118 & 7 & 108 & 7 & 92 & 103 & 95 \\
\hline 8 & LAGT x RIT & 135 & 7 & 122 & 7 & 90 & 119 & 98 \\
\hline 9 & LAGT x TAGT & 135 & 7 & 124 & 8 & 92 & 119 & 96 \\
\hline 10 & LAGT x WAT \& WAT x LAGT & 137 & 8 & 118 & 7 & 86 & 117 & 99 \\
\hline 11 & RIT x BAYT & 108 & 6 & 95 & 6 & 88 & 91 & 96 \\
\hline 12 & RIT x TAGT & 124 & 7 & 117 & 7 & 94 & 112 & 96 \\
\hline 13 & WAT x BAYT & 119 & 7 & 111 & 7 & 93 & 110 & 99 \\
\hline 14 & WAT X RIT & 117 & 6 & 113 & 7 & 97 & 113 & 100 \\
\hline 15 & WAT x TAGT & 111 & 6 & 105 & 6 & 95 & 105 & 100 \\
\hline \multicolumn{2}{|c|}{ TOTAL/MEAN } & 1,807 & 100 & 1,649 & 100 & 91 & $\mathbf{1 , 5 9 5}$ & 97 \\
\hline
\end{tabular}

Table 2. Vegetative data of Syn Var entries seven (7) years from field planting

\begin{tabular}{|c|l|c|c|c|}
\hline No. & \multicolumn{1}{|c|}{ Cross } & $\begin{array}{c}\text { Existing Palms } \\
(\mathbf{n o})\end{array}$ & $\begin{array}{c}\text { Annual Leaf } \\
\text { (Production (no) }\end{array}$ & $\begin{array}{c}\text { Girth } \\
(\mathbf{c m})\end{array}$ \\
\hline 1 & BAOT x BAYT & 77 & 19 & 203.7 \\
\hline 2 & BAOT x RIT \& RIT x BAOT & 119 & 18 & 195.8 \\
\hline 3 & BAOT x TAGT & 89 & 19 & 203.1 \\
\hline 4 & BAOT x WAT \& WAT x BAOT & 119 & 19 & 197.2 \\
\hline 5 & BAYT x TAGT & 127 & 18 & 205.5 \\
\hline 6 & LAGT x BAOT & 105 & 18 & 203.5 \\
\hline 7 & LAGT x BAYT & 108 & 18 & 207.6 \\
\hline 8 & LAGT xIT & 122 & 18 & 202.5 \\
\hline 9 & LAGT x TAGT & 124 & 19 & 207.1 \\
\hline 10 & LAGT X WAT \& WAT x LAGT & 118 & 19 & 197.8 \\
\hline 11 & RIT x BAYT & 95 & 17 & 199.7 \\
\hline 12 & RIT X TAGT & 117 & 18 & 194.0 \\
\hline 13 & WAT x BAYT & 111 & 18 & 199.5 \\
\hline 14 & WAT X RIT & 113 & 18 & 193.7 \\
\hline 15 & WAT x TAGT & 105 & 18 & 200.6 \\
\hline & \multicolumn{1}{|c|}{ TOTAL / MEAN } & $\mathbf{1 0 4 9}$ & $\mathbf{1 8 0 0 . 8}$ \\
\hline
\end{tabular}

entries ranging from 17 to 19 leaves per annum and girth sizes ranging from 194 to $208 \mathrm{~cm}$ (Table 2). These observations indicate the even response of the entries to the cultural management techniques applied and the absence of genotypic influence on these growth parameters.

Flowering distribution. Unlike leaf production and girth size, flowering distribution and frequency varied among the entries with some hybrids flowering earlier than the others (Figure 3). It was interesting to note that flowering occurred as early as 2.5 years from field planting in two entries, BAYT x TAGT ( 2 palms) and WAT x TAGT (1 palm). At the age of 3.5 years, the hybrid WAT $x$ RIT showed $50 \%$ flowering while the hybrid BAOT $x$ TAGT was barely starting to flower. Five years after planting, nine hybrids reached more than $80 \%$ flowering and by the seventh year, two hybrids, i.e. WAT $x$ RIT and WAT $x$ TAGT, showed $100 \%$ flowering. As of March 2000 or at the 
age of seven and a half years from field planting, $97 \%$ of the palms have reached the reproductive stage (Table 1).

Floral Biology. After the El Niño phenomenon in 1998, majority of the flowering palms resumed normal emission of spathes. This situation paved the way for the conduct of floral biology observations that could be used in predicting the possible genotypes of open pollinated progenies of specific palms. As shown in Table 3, the range of interval between successive emissions of spathes from January to August 1999, is from 19 to 22 days with very minimal overlapping between successive spathes. On the average, the length of the male phase was 22.3 days among all entries with BAYT $x$ TAGT showing the shortest at 20.5 days and the WAT $x$ BAYT having the longest. The female phase, on the other hand, ranged from 3 days in BAYT $\mathrm{x}$ TAGT, LAGT $x$ BAYT and LAGT $x$ TAGT to 4.3 days in BAOT $x$ WAT or an average of 3.34 days. Depending on the hybrid, intra spadix overlapping of the sexual phases was common although with very short duration of at least half a day to a maximum of 3.1 days. Similarly, the overlapping of the male and female phases between successive spathes was of short duration ranging from 17 hours in WAT $x$ BAYT to more than 3 days in RIT $x$ BAOT and LAGT $x$ RIT.

Pattern of Pollen dispersal. To determine the presence of coconut pollen inside the emerging plantation, and possible crosspollination among the individual palms, observations on pollen dispersal patterns were conducted from July 1996 to November 1999 within the SYN VAR block. Pollen traps consisting of four glass slides which were wiped with petroleum jelly on both sides and mounted on a Styrofoam frame for maximum exposure were placed in between sample palms at varying heights, e.g., 5, 7 and $8 \mathrm{ft}$ from the ground and at four time frames, e.g., 7-10 AM, 10-1 PM, 13:30 PM and 3:30 PM to $7 \mathrm{AM}$ of the following day. The four slides were oriented in a manner wherein each would face one direction.

While the transition to the flowering phase started rather early, i.e. July 1996, the dispersal of pollen within the SYN VAR block was not very high and in fact, considered negligible. It only went up to as high as 32-pollen grains $/ \mathrm{cm}^{2}$ $\left(\mathrm{pgs} / \mathrm{cm}^{2}\right)$ in October 1999 from almost nil in July 1996 (Figure. 4). More pollen was trapped between $10 \mathrm{AM}$ to $1 \mathrm{PM}$ (e.g., $2.1 \mathrm{pgs} / \mathrm{cm}^{2}$ ) than from the other three time frames (Figure. 5). This could be explained by the fact that majority, if not all of inflorescences open before 10 AM. It was also worth noting that although pollen dispersal seemed to be not affected by (wind) direction, there was slightly more pollen trapped on the slides facing West and South than from East and North (Figure. 6). It appears that the canopy of the palms has affected air movement

Table 3. Floral biology of $\mathbf{t} x \mathrm{t} \mathrm{F}_{1}$ hybrids, PCA Syn Var 001 (January to August 1999)

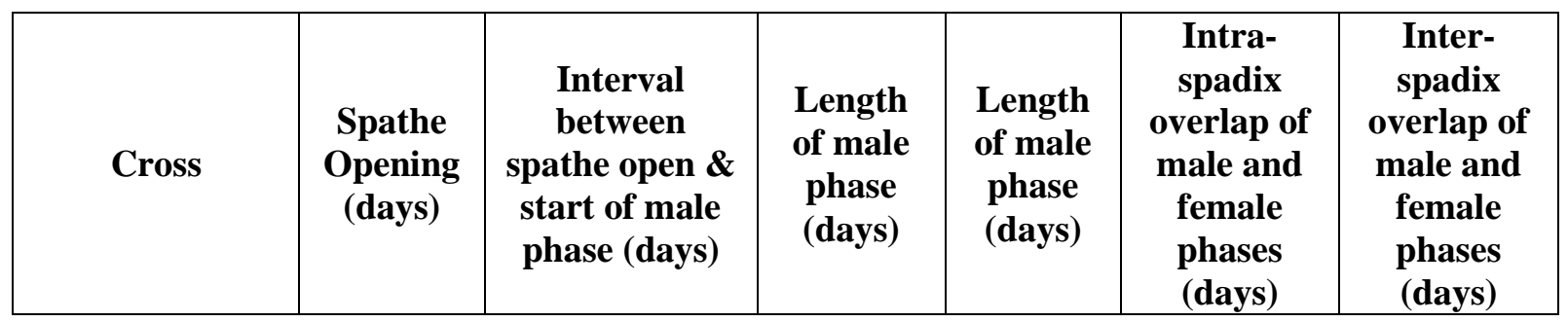




\begin{tabular}{|l|c|c|c|c|c|c|}
\hline RIT x TAGT & 20.8 & 0 & 21.9 & 3.3 & 0.5 & 2.5 \\
BAOT x WAT & 21.3 & 0 & 22.0 & 4.3 & 1.5 & 2.3 \\
WAT x LAGT & 19.9 & 0 & 23.6 & 3.2 & 2.9 & 2.7 \\
BAYT x TAGT & 21.3 & 0.2 & 20.5 & 3.0 & 0.5 & 1.5 \\
WAT x RIT & 21.9 & 0.1 & 23.3 & 3.4 & 1.9 & 3.0 \\
RIT x BAOT & 19.0 & 0.1 & 21.3 & 3.2 & 0.3 & 3.6 \\
WAT x TAGT & 21.5 & 0 & 22.1 & 3.6 & 1.2 & 1.7 \\
RIT x BAYT & 21.2 & 0 & 22.2 & 3.3 & 2.3 & 1.6 \\
LAGT x BAYT & 19.9 & 0 & 23.5 & 3.0 & 3.1 & 2.1 \\
LAGT x TAGT & 19.9 & 0 & 22.7 & 3.0 & 1.7 & 3.0 \\
LAGT x RIT & 19.5 & 0 & 21.9 & 3.3 & 1.0 & 3.6 \\
WAT x BAYT & 22.6 & 0.1 & 24.7 & 3.5 & 1.7 & 0.7 \\
LAGT x BAOT & 19.5 & 0 & 21.8 & 3.2 & 1.1 & 3.3 \\
BAOT x BAYT & 20.3 & 0 & 21.2 & 3.5 & 1.7 & 2.1 \\
BAOT x TAGT & 20.5 & 0 & 21.6 & 3.3 & 1.7 & 2.4 \\
\hline \multicolumn{1}{|c|}{ MEAN } & $\mathbf{2 0 . 6}$ & $\mathbf{0 . 0}$ & $\mathbf{2 2 . 3}$ & $\mathbf{3 . 3}$ & $\mathbf{1 . 5}$ & $\mathbf{2 . 4}$ \\
\hline
\end{tabular}

Figure 3. Flowering distribution of Synvar entries

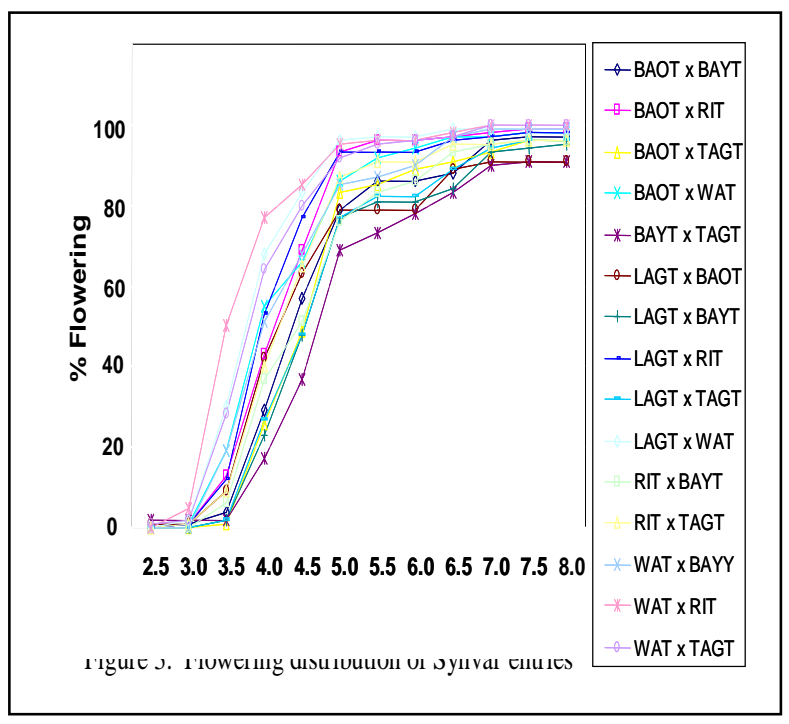

(insect pollination notwithstanding) and somewhat influenced this observation. The randomized field layout and atmosphere conditions which permit a multi-directional windy condition, i.e. $>3 \mathrm{mi} / \mathrm{hr}$, might have generated favorable phenotype interactions in the populations.

Survival rate and number of palms. The original plan for the study was to plant at least 100 seedlings of more or less similar ages per
Figure 4. Pollen dispersal per day by period

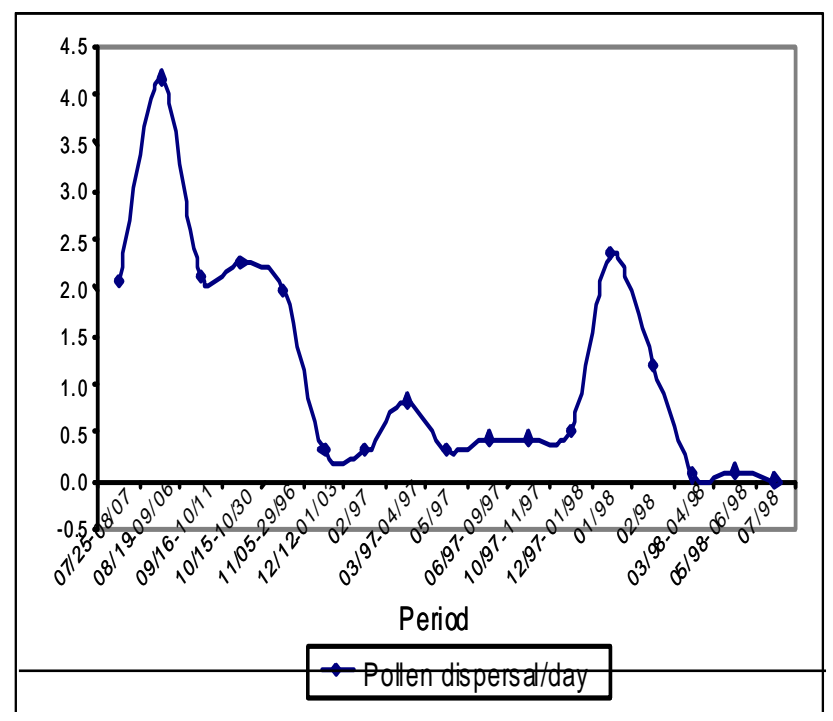

cross but this was not achieved to the fullest extent. Hybrid representation ranged from 5 to 8 percent (Table 1). At the start, the number of palms per hybrid variety ranged from 92 for BAOT $x$ BAYT palms to a maximum of 142 palms for BAOT $x$ RIT. After seven years, the number of palms was reduced a little with BAOT $x$ BAYT having 75 palms, 119 for BAOT $x$ RIT, LAGT $x$ RIT and LAGT $x$ TAGT. It is obvious that the hybrids with more palms would have better chances of mating than those with fewer palms. Nevertheless, since the 
pedigree, the rates of survival of each hybrid and location of each palm in the field are known, and taking into account the respective yield of each entry, it would be easy to come up with a sampling technique for the next SYN generations $\left(\operatorname{Syn}_{\mathrm{n}}\right)$.

Early yield. From a total of 1,649 palms, 97\% are already productive as of March 2000. While it is still too early to make a good comparative assessment of the nut and copra production of the hybrids, the early yields recorded show some good trends. The first nuts were harvested as early as 1996 but these are negligible. However, during 1997 to 1999 or at an early age of a little over seven years from planting, three hybrids, e.g. BAOT $x$ WAT, WAT $x$ TAGT and BAYT $x$ TAGT, produced an annual average of 4,458 to 6,032 nuts or 1.5 to 1.7 tons of copra per hectare (Appendix Table 1). Three hybrids, namely WAT $\mathrm{x}$ RIT, BAOT $\mathrm{x}$ BAYT and WAT $x$ BAYT, followed closely with an annual mean nut production of 4,456 to 4,659 nuts or copra yields of 1.4 tons per ha. It is worth noting that WAT $\mathrm{x}$ TAGT and BAYT $\mathrm{x}$ TAGT hybrids were also the first ones to flower. The higher copra production of these hybrids as compared to others may be associated to their better copra per nut and higher number of nuts, which are both highly heritable and desired traits.

Fruit Component Characters. As expected, since the parents of the hybrids are tall varieties that were selected for nut size, all entries produced medium to large nuts depending on the cross combination. Notably, two crosses with RIT, e.g. RIT $x$ TAGT and BAOT $x$ RIT, produced nuts weighing more than $1.6 \mathrm{~kg}$ on the average (Table 4). Rennel Island tall is an exotic variety and is world renown for large sized nuts. It is also apparent that crosses with WAT, a relatively smaller seeded variety, inherited the large size of nuts from the other varieties. This general trait suits the preference of farmers for good (practical and economic) reason. Normally, harvesting and post harvest expenses in a coconut farm are based on number of nuts in smallholdings.
Bulking of seeds. Theoretically, the performance of the next generation SYN should not vary very much even with varying genotypes for as long as the heterozygozity of the SYN populations is maintained. The only aspect, which is time consuming, is the detailed labeling of the nuts from palm to palm for future studies on molecular analysis and to create a balanced second generation SYN.

Bulking of seeds from all crosses is currently being done for distribution to the Regional offices of the PCA. Seednuts would be raised in standard polybag nurseries. When ready, seedlings would be planted in isolated fields of at most 50 hectares per province. The aim is to mass produce $\operatorname{Syn}_{n}$ seednuts and distribute these to farmers, ad infinitum.

Use of molecular marker technology. A study was done to understand the genetic structure of the coconut synthetic variety using morphological parameters and microsatellite markers (Akuba 2002). The morphological parameters consisted of fruit component characters and performance based on the STANTECH Manual (Santos et al 1996). For the molecular evaluation, 7 SSR primer pairs were used namely CN2A4, CNZ51, CNZ18, CNZ21, CNZ09, CN1G4 and CN1C6. These primers were isolated and characterized by Rivera et al. (1999) and have discriminating power greater than 0.99 (Carcallas 2001, and Segovia et al 1999).

This study was the first ever conducted on the PCA SYN VAR base population, which other workers considered as a composite variety instead of a synthetic variety. Nevertheless, the findings and conclusions pointed out confirmed some of the expected practical applications of the Syn Var approach on coconut varietal improvement.

First, while the genetic structure of the first filial generation of the Syn Var is not stable, the high quality of fruit components of its parents favor the use of the second generation as planting materials by farmers that would redound to higher copra yields. Second, the first 
filial generation would have genotypes that would be good for tissue culture.

The $\mathrm{Syn}_{0}$ diverged into two main groups of hybrids based on SSR data at a distance of 0.25 to 0.5 (Figure 7). Group I consisted of the hybrids with local tall varieties as female parents. Group II consist of hybrids with foreign tall varieties (RIT and WAT) as female parents except LAGT x WAT.

Meanwhile, cluster analysis based on fruit components data reveals that parental populations of $\mathrm{Syn}_{0}$ are genetically diverse (Figure 8). There are three main groups identified on distance 0.50.6. Group I was mostly the hybrid with local tall as female parents (except RIT x BAYT). This group diverged into two sub-groups. Sub-group I was made up of hybrids in which one of the parents is either LAGT or BAOT. Sub-group II consisted of hybrids with one of the parents was RIT or TAGT. Group II included hybrids with WAT as female parent except for LAGT $\mathrm{x}$ WAT. The BAOT $x$ RIT and RIT $x$ TAGT hybrids separated as Group III. These hybrids had larger fruits than the other hybrids. The correlation between average taxonomic distances and delta $\mu^{2}$ distances were weak $(r=0.127)$ and nonsignificant. In general, the grouping of hybrids comprising $\mathrm{Syn}_{0}$ population based on SSR markers and fruit component characters matched in terms of separating the hybrids with local

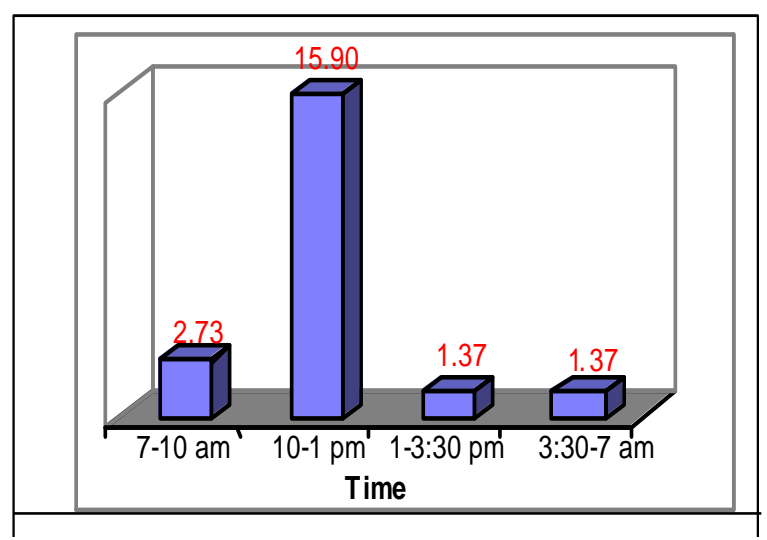

Figure 7. Dendrogram of $F_{1}$ hybrids comprising Syno based on SSR data

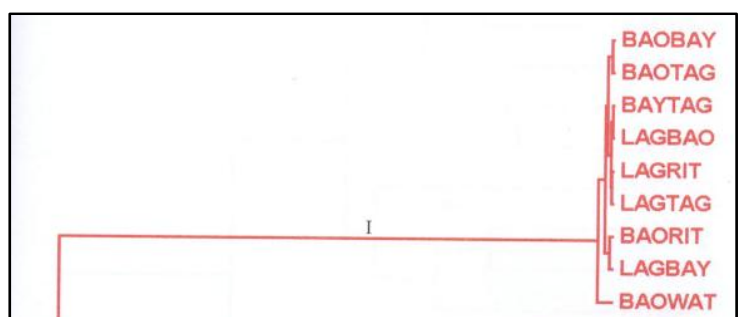

female parents (LAGT, BAOT, BAYT and TAGT) from the hybrids with foreign female parents (RIT and WAT).

The $\operatorname{Syn}_{1}$ differentiated into three main groups based on delta $\mu^{2}$ distance (Figure 9). Group I was made up of $\mathrm{Syn}_{1}$ from hybrids between BAOT and BAYT, TAGT, RIT and WAY, and BAYT x TAGT. Group II included $\mathrm{Syn}_{1}$ from hybrids with LAGT as female parent. Group III was the hybrids between foreign tall varieties and TAGT, BAYT and RIT, including LAGT x RIT.

The genetic relationship of $\operatorname{Syn}_{1}$ population derived from different hybrids based on seedling vigor characters is presented in figure 10 . The average taxonomic distances between hybrids resulted in three groups that generally did not match the grouping based on microsatellite markers. $\mathrm{Syn}_{1}$ derived from hybrids from one of the parents was BAOT belonged to Group I, including RIT x BAYT. Group II consisted of hybrids with female parent LAGT except LAGT x RIT. The hybrids with female parents RIT and WAT made up of Group III. The correlation between average taxonomix distances (seedling vigor) and delta $\mu^{2}$ distances were low $(r=0.136)$ and nonsignificant. In general, grouping of $\operatorname{Syn}_{1}$ derived from $\mathrm{F}_{1}$ hybrids $\left(\mathrm{Syn}_{0}\right)$ based on

Figure 5. Pollen as by 4 time frames

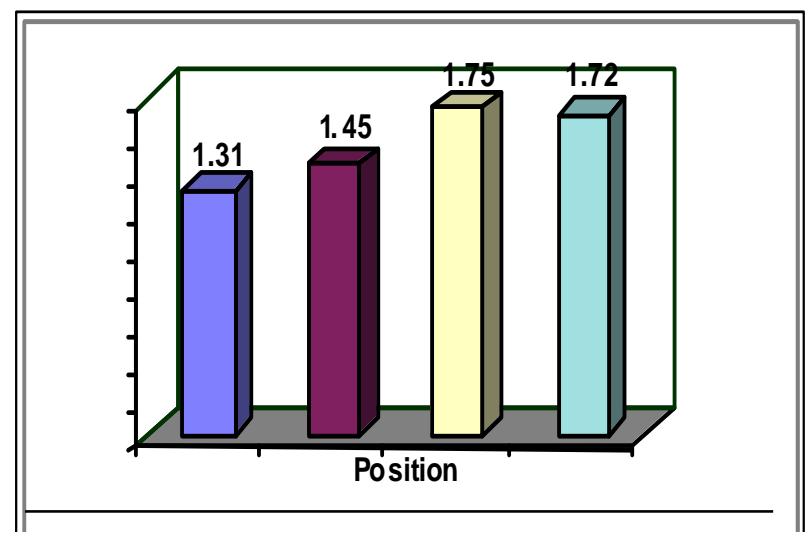

Figure

Figure 8. Dendrogram of $F_{1}$ hybrids comprising Syno based on component data

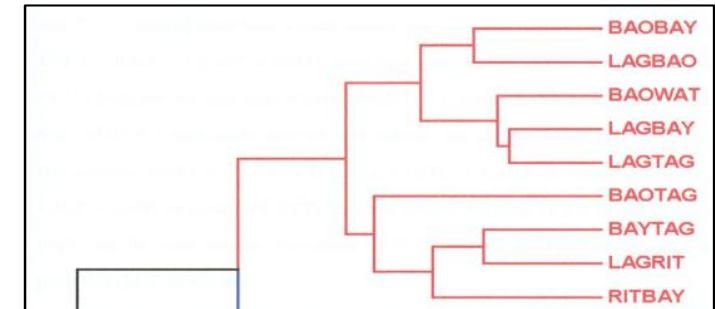


Figure 9. Dendrogram of $\operatorname{Syn}_{1}$ based on delta $\mu^{2}$ distance derived from $F_{1}$ hybrids ( $\mathbf{S y n}_{0}$ )

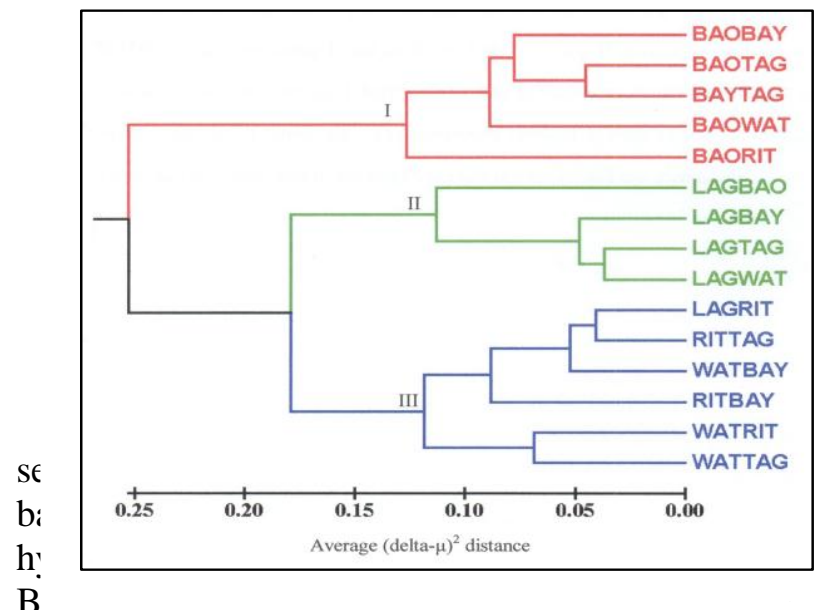

and RIT $x$ TAGT hybrid clustered with the LAGT hybrid group.

The low correlation between average taxonomic distances based on fruit component and seedling vigor, and delta $\mu^{2}$ distances for SSR markers are due to factors that affect the expression of polygenic traits (quantitative traits) such as dominance, epistasis, pleitropy, and environmental effects (Liu 1998, and Guarino et al. 1999). Reed and Garkham (2001) mentioned the six factors responsible for this low correlation namely non-additive genetic variation, differential selection, and impact of regulatory variation, mutation, low statistical power, and environment.

Utilization as planting materials. In 2004, a total of 48,944 seednuts and 12,721 seedlings
Figure 10. Dendrogram of Syn 1 derived from $F_{1}$ hybrids $\left(\operatorname{Syn}_{0}\right)$ based on vigor of seedling

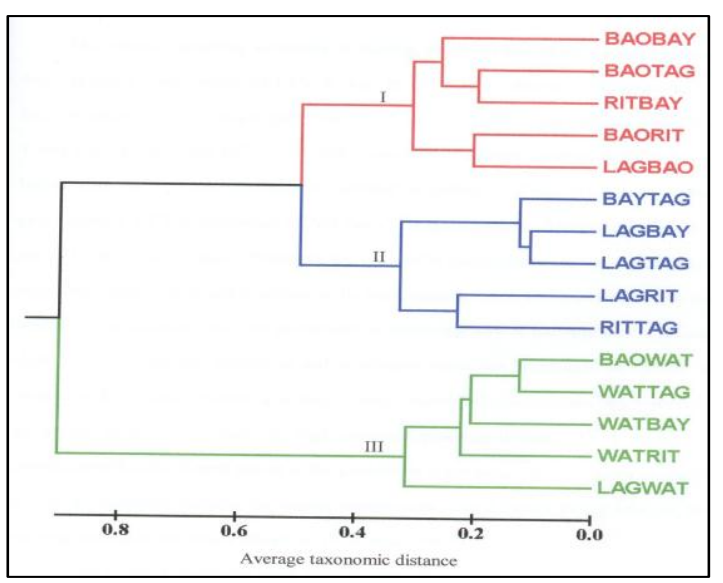

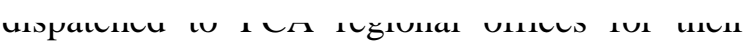
planting and replanting activities (Figure 11). To date, 374,913 Syn Var seednuts and seedlings had been distributed nationwide for the regional replanting activities and for the establishment of coconut seedfarms. This figure is good enough to cover 1,678 ha of coconut farms (Appendix Tables 2 and 3).

Yield of $\mathbf{S y n}_{\mathbf{0}}$ - Appendix Table 4 shows the yield potential of the hybrids comprising $\mathrm{Syn}_{0}$ generation. Based on the initial assessment heterosis is found in the $15 \mathrm{~F}_{1}$ variety hybrids ranging from $3-23 \%$ per copra weight per nut. As expected, the choice of two foreign varieties, RIT and WAT proved wise because it increased the degree of heterosis when they are crossed with the local varieties. In contrast TAGT crosses with local talls except BAOT, showed lower heterosis as compared 
with the local $\mathrm{x}$ foreign tall crosses. Heterobeltiosis ${ }^{6}$ is found in 7 crosses; BAOT $\mathrm{x}$ BAYT, BAOT $x$ RIT, BAOT $x$ TAGT, LAGT $\left(\mathrm{S}_{1}\right)$ x BAYT, LAGT $\left(\mathrm{S}_{1}\right) \times$ RIT, RIT x TAGT and WAT $x$ BAYT.

Figure 11. GMA FV hybrid seednuts unloaded in the designated selection area

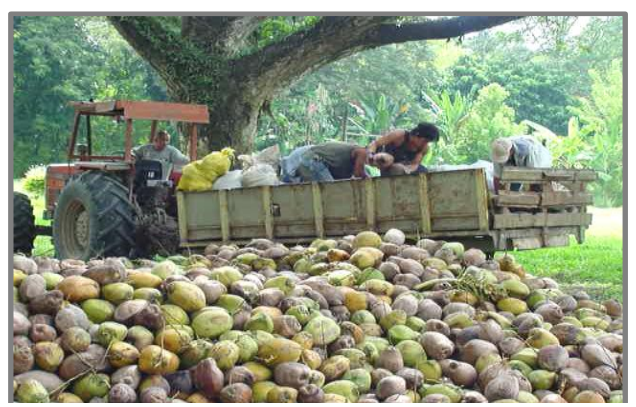

Yield performance for 2004. Except for BAOT $x$ RIT, LAGT $x$ TAGT and BAOT $x$ TAGT, all entries recorded slightly lower C/N ($4.7 \%$ ) this year than the previous year. However, nut production increased by an average of $17.7 \%$. As a result, copra yields increased by $13.3 \%$. Only WAT x RIT recorded a very slight decrease in copra yield/ha, i.e. 2.75 tons in 2003 vs. 2.72 tons in 2004. However, no $\mathrm{t} \times \mathrm{t} \mathrm{F}_{1}$ hybrids recorded copra yields below 2.3 tons/ha. On top of this, six out of the $15 \mathrm{t} \times \mathrm{t}$ hybrid entries produced at least 3.0 tons copra/ha, i.e. yield range of 3.0 to 3.8 tons.

Twelve years after the field planting of $\mathrm{t} x \mathrm{t}$ $F_{1}$ hybrid base populations, the coconut synthetic variety $\left(\mathrm{Syn}_{0}\right)$ demonstrated its yield stability. Mean yield from 2001 to 2004 ranged from 2.53.5 tons copra/ha. Majority of the $\mathrm{t} \times \mathrm{t} \mathrm{F}_{1}$ hybrid base populations performed above the mean yields with more below 3.5 tons copra/ha. While some entries performed below the mean yields, they did not fall below 1.5 tons copra/ha (Figure 12).

Figure 12. Yield trend of GMA FV hybrid base populations, 2001-2004

\footnotetext{
6 Heterobeltiosis - a phenomenon whereby the progeny of a cross is better than the better parent
} 


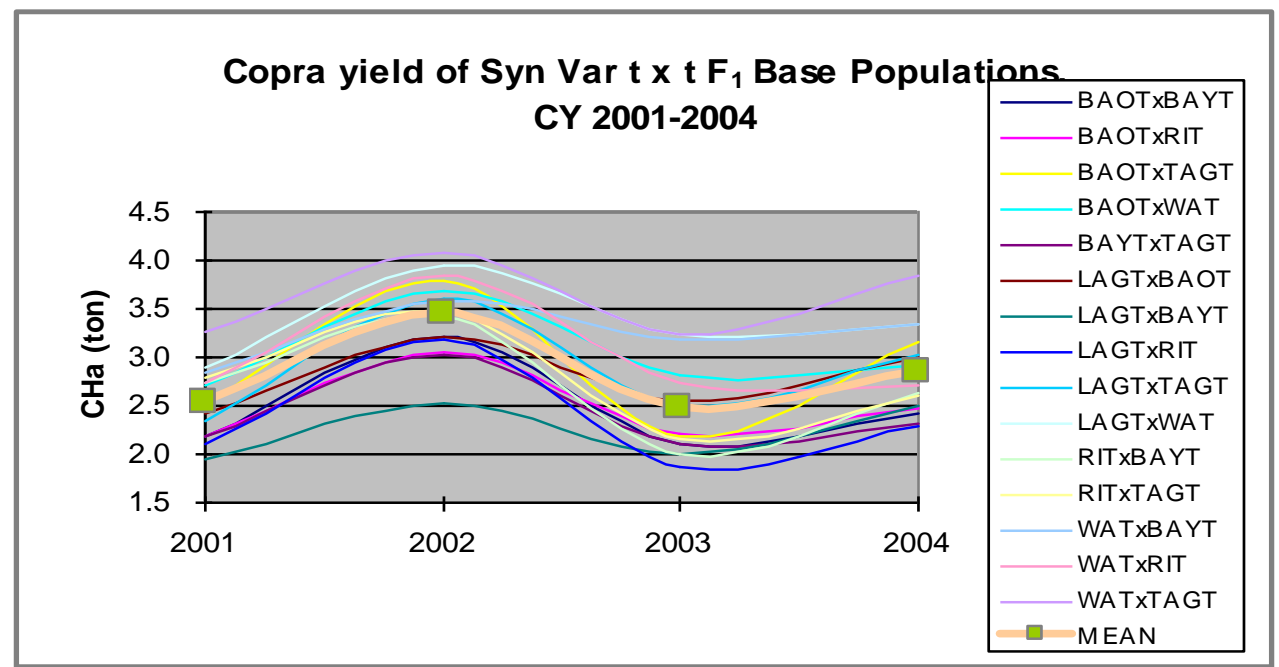

\section{Summary and Conclusion}

As increased genotypic heterozygosity through phenotypic disassortative mating improves vigor and yield performance of progenies while inbreeding causes depression, the use of $F_{2}$ seeds from $F_{1}$ variety hybrids could lead to disastrous results. Knowing the bias of coconut farmers in using seeds from any high yielding variety for successive cropping, the development of an OPV like SYN with a high degree of balanced heterozygozity is highly desirable.

Started in 1979, the current project aimed at developing a SYN coconut variety, has come a long way. The results so far gathered point to the possibility of having a compromise breeding method that is applicable to coconut other than simple mass selection and breeding for hybrids that has long been practiced. If the trend continues, the genetic materials on hand may be exploited in many ways. For instance, it would be possible to do some selective temporal and/or spatial harvesting to generate relevant genotypes for other studies. In fact, controlled close breeding between selected $F_{1 S}$ is being contemplated to determine the effect of specific combinations to supply relevant genotypes for tissue culture studies, which the PCA has been doing.
Microsatellites or simple sequence repeats (SSRs) markers could discern between phenotypically similar varieties and/or plant types with heterozygous genotype even at the nursery stage. The application of this robust DNA technology would facilitate current efforts on the development of OPVs in particular the PCA Syn Var 001 from 15 variety hybrids.

While the Syn Var project was originally conceived to be totally dependent on the coconut breeder's unique instinct on individual palm selection, the application of this novel technology could pave the way for the efficient assessment of breeder's breeding populations as well as generate needed information on the level of genetic diversity of existing stands of coconut in farmer's fields. When achieved, the breeder will thus have the opportunity to quickly frame up an effective way of mass-producing the seeds for eventual multiplication of the relevant genotypes for coconut growing communities. This project is unique and the first of its kind in the world. It offers great opportunities for all coconut farmers in the Philippines.

At the current rate of nut production in the SYN VAR field at ZRC, it would be possible to plant 360 hectares, rising to 650 hectares per year over the next 50 years. These in turn could commence another round of distribution after seven years or earlier to the tune of 9,700 ha per year and so on and so forth. 
The coconut palm may be slow in growth and development, and has a low capacity for multiplication. When it matures, however, it has a very long life span that could outlast its users. It becomes an inexhaustible source of food and non-food raw materials and increased income for farmers. And one noteworthy and very desirable attribute, it can serve as an exuberant spring of foundation seeds for the breeder. Using the participatory research approach, coconut farmers who received the seednuts from SYN project would have a means of producing their own seeds and provide seeds to their neighbors thus ensuring a continuing replanting program with minimum intervention from the government. The latter is one exceptional situation, which draws special interest because it offers a means of maintaining the dramatic inter-population heterosis between the varieties used from generation to generation and at the same time overcoming the basic problem of inadequate seednuts. Certainly, this project has transformed the basic disadvantages of coconut into possibilities and opportunities.

\section{Next Steps to be undertaken}

Exploit the SSR marker technology in accelerating the development of coconut breeding lines for the PCA Syn Var project and isolate superior breeding populations for coconut seedfarm establishment.

1. Identification of genetic diversity in PCA Syn Var parental and base populations and analysis of their genetic relationships using molecular and morphological markers. The genetic structure and diversity of Syn Var parental populations will be established using molecular markers specifically microsatellite marker technique. Genetic diversity of the base population will be assessed based on number of polymorphic loci, allelic richness, \% heterozygosity and the kind of alleles present. Genetic relationships between parental populations will be ascertained by estimating genetic distances using morphological and molecular markers. Discriminant SSR markers will be used to determine the molecular profile of the succeeding Syn Var generations.

2. Establishment of $\mathrm{GMAFV}^{7}$ coconut seedfarms in a coconut farming community using genetically enhanced parental lines from the PCA Syn Var.

Sustainable and highly productive 50hectares coconut seedfarms will be established in strategic sites of the 70 coconut-growing provinces of the country using genetically enhanced parental lines from the second filial generation of the PCA's Synthetic Variety at the Zamboanga Research Center.

\section{Implications and Recommendations}

The objectives of developing early maturing and highly open pollinated variety that will support a century of planting program with superior planting materials or to produce a family of palms having highly balanced heterozygosity and develop breeding scheme that would allow these individuals to maintain balanced heterozygosity from generation to generation are considered very ambitious research undertakings. However, the use of molecular marker technologies, e.g. microsatellite marker techniques (SSRs), for coconut research provides opportunities for assessing and evaluating the breeding value of the genetic materials at the DNA level.

This continuing research undertaking aims not only provide information on the genetic structure of the resultant populations from the PCA SYN VAR foundation parents with that of the DNA patterns of the inter-crossed $F_{1}$ hybrids, but also more importantly apply the DNA molecular marker technology to identify and select superior materials at the earliest time possible, i.e. seedling stage, for the establishment of coconut seedfarms. The application of DNA marker technologies that

\footnotetext{
${ }^{7}$ GMA - Genetically Multi-Ancestored Farmer's Variety
} 
will complement existing classical coconutbreeding strategies is expected to accelerate the establishment of coconut seedfarms using PCA Synthetic Variety and provide the necessary genetic diversity in future coconut stands.

\section{Acknowledgement}

The authors whole-heartedly acknowledged the recent funding support from the Department of Science and Technology (DOST) through the Philippine Council for Agriculture, Forestry and Natural Resources Research and Development Council (PCARRD) for the PhP 1M 2003 PANTAS Award Research Grant as well as from the Department of Agriculture (DA) through the Bureau of Agricultural Research for another PhP 1M 2004 GAWAD SAKA Award Research Grant; and the long-term funding assistance from the Philippine Coconut Authority (PCA) through the Research, Development and Extension Branch (RDEB).

The authors likewise deeply recognize the technical contributions and assistance including financial collaboration from the following local and international research institutions:

- $\quad$ The Institute of Plant Breeding, College of Agriculture, University of the Philippines at Los Baños;

- The International Plant Genetic Resources Institute (IPGRI) through the International Coconut Genetic Resources Network (COGENT); and

- The Long Ashton Research Station, Department of Agricultural Sciences, University of Bristol, United Kingdom.

\section{References}

Akuba, R. H. 2002. Breeding and population genetics studies on coconut (Cocos nucifera L.) composite variety using morphological and microsatellite markers. UPLB, College, Laguna, Unpublished Ph $\mathrm{D}$ thesis. $230 \mathrm{p}$.
Allard, R.W. 1960. Principles of Plant Breeding. Wiley, New York and London.

Baliñgasa, E.N. and C B Carpio, 1976. Genetic potential of some coconut populations in the Philippines. PCA-ARB Annual Report (1975 - 1976): 7-19.

Baliñgasa, E.N. and G.A. Santos 1978. Manual for coconut hand pollination technique. Breeding and Genetics Division, PCAARB, Davao Research Center, BagoOshiro, Davao City.

Banzon, J.A. and J.R. Velasco. 1982. Coconut Production and Utilization. PCRDF Amber Ave, Pasig, M. Manila.

Bos, L. 1985 Fundamentals of plant breeding. IAC, Wageningen, The Netherlands.

Bourdeix, R. 1988. Efficacite de la selection massale sur les composantes du rendement chez de cocotier. Oleagineux 45:359-371.

Carcallas, R.J.U. 2001. Evaluation of microsatellite primers to determine effective number of sample size for genetic diversity analysis of coconut (Cocos nucifera L.), University of the Philippines at Los Baños (UPLB) MS Thesis, $92 \mathrm{p}$

Chan, E. 1978. Growth and early yield performance of Malayan Dwarf $\mathrm{x}$ tall coconut hybrids on the coastal clays of Peninsular Malaysia. Proc. Int. Couf. On Cocoa and Coconuts. June 21-24, 1978, Kuala Lumpur, p.522-531.

Cockerham, C.C. and B.S. Weir. 1984. Covariances of relatives stemming from a population undergoing mixed self and random mating. Biometrics 40:157-164

De Nuce De Lamothe, M. and F. Rognon 1972. La production de semences hybrides chez 
Ic cocotier par fecondation naturelle dirigee. Oleagineaux 27(10): 483-488.

De Nuce de Lamothe, M. and W. Wuidart, 1980. Tall coconuts at Port Bouet (Ivory Coast). I. West African tall, Mozambique tall, Polynesian tall and Malayan tall. Oleagineaux 34(7): 339-334

De Nuce de Lamother, M. and G. M. de Bernard. 1995. L'hybride de Cocoties PB 121 (ou MAWA), NJM x GOA. Oleaginueux 40:261-266.

Frempnd, Y. R. Ziller and M. De Nuce de Lamothe, 1966. The coconut palm. International Potash Inst. Switzerland, $227 p$.

Gemperle, F.R. and Y.L. Fremond, 1978. Tagnanan coconut population: A promising breeding material. Proc. Int. Conf On Cocoa and Coconuts. June 21-24, 1978, Kuala Lumpur. P.500-507

Guarino, L.V., Ramanatha R., and P. Batugal 1999. Collecting coconut genetic diversity: Elements of a strategy for COGENT germplasm collecting activities. Papers presented on ADB and IFAD-funded projects Annual Meeting. Kuala Lumpur, Malaysia. October 28-November 4, 1998. $20 \mathrm{p}$

Kramer, Tb. 1985. Selection methods in plant breeding. IAC, Wageningen, The Netherlands.

Lande, R and R. Thompson. 1990. Efficiency of marker-assisted selection in the improvement of quantitative traits. Genetics 124:743-756.

Lee, M. 1995. DNA markers and plant breeding programs Advances in Agronomy 55:265344

Liu, B.H. 1998. Statistical genomics. Linkage, mapping and QTL analysis. CRC Press New York pp 45-83.
Luntungan, H.T. 1997. Evaluasi dan pengembangan kelapa hybrid (Evaluation and development of coconut hybrid). In: Novarianto, H., R. H. Akuba, M. L. A. Hosang, M.M. Rumokoi, R.B. Maliangkay, Arie Lolong, and Amrizal. Prosiding Temu Usaha Perkelapaan Nasional, 6-8 Januari 1997, Manado, Indonesia. P120-135.

Mendoza, A.M.R. and E.N. Baliñgasa, 1978. Coconut genetic resources collection in the Philippines. Paper presented, 1978 IBPGR Consultation on Coconut Genetic Resources, FAO, Rome.

Meunier, J. 1992. Genetic diversity in coconut: a brief survey of IRHO's work. In: Coconut genetic resources. Pp59-62. Paper of IBPGR workshop, Cipanas, Indonesia, October 8-11, 1991 International Crop Network Series No. 8 IPGRI, Rome

Novarianto, H. 1987. Analisis kuantitatif karakter agronomic dan analisi isozim daun kelapa hibrida (genjah $\mathrm{x}$ dalam) dan tetuanya. Tesis Pascasarjana. IPB. Bogor. 58p.

Reed, D.H. And R. Frankham. 2001. How closely related are molecular and quantitative measures of genetic variation? A meta-analysis. Evolution 55(6):1095-1103.

Rivera, R., K. J. Edwards, J. H. A. Barker, G. M. Arnold, G. Ayad, T. Hodgkin, and A. KARP. 1999. Isolation and characterization of polymorphic microsatellites in Cocos nucifera L. Genome 42:668-675.

Rompas, T.H., H.T. Luntungan, and H. Novarianto. 1988. Metode pemuliaan kelapa (Coconut breeding methods). Prosiding Lokakarya Pemuliaan Tanaman Cengkeh, Lada, Kapas, dan Kelapa. Puslitbangtri Bogor. P27-39. 
Santos, G.A., E.N. Baliñgasa and C.B. Carpio. 1979. Selection of base populations for use in coconut hybridization. Paper presented at the 10th Annual Scientific meeting of the Crop Science Society of the Philippines. April 23-25, 1979, UPLB, College Laguna.

Santos, G.A., R.T. Bahala and S.B. Cano. 1989. Development of a synthetic variety of coconut PCA ARB Annual Report (1989): 132-135.

Santos, G.A., and A. Sangare. 1992. Evaluation and utilization of coconut genetic resources. COGENT. p70-78.

Santos G.A., P.A. Batugal, A. Othman, L. Baudouin, and J.P. Labouisse. 1996. Manual on Standardized Research Techniques in Coconut Breeding. IPGRICOGENT publication. Stanford Press, Singapore 100p.

Santos, G.A. 1997. Advances in coconut breeding and production. Paper presented at the Coconut Symposium held at BSWM, Elliptical Rd., Quezon City, August 28-29, 1997.

Satyabalan, K. And M.S. Laksmanachar 1960. Coconut breeding: effects of some breeding procedures. Indian Coconut Journal 13:94100.

Segovia, S.J.E., N.O. Bituin, R.J.U. Carcallas, C.C. Reaño, R. Rivera, G.A. Santos and D.M. Hautea. 1999. Genetic diversity assessment in coconut using morphological and microsatellite markers. Abstract Paper. The Philippine J. of Crop Sci., 24(1): 106

Simmonds, N.W. 1979. Principles of crop improvement. Longman, London and New York. 
Appendix 1. Fruit component characters and early nut and copra yields of Syn Var entries

\begin{tabular}{|c|c|c|c|c|c|c|c|c|c|c|c|c|}
\hline \multirow{2}{*}{$\begin{array}{c}\text { Hybrid } \\
\text { Cross }\end{array}$} & & \multirow{2}{*}{$\begin{array}{c}\text { Whole } \\
\text { Nut } \\
\text { (g) }\end{array}$} & \multicolumn{5}{|c|}{ W E I G H T (g/per nut) } & \multirow{2}{*}{ FQV } & \multirow{2}{*}{$\begin{array}{l}\mathbf{N} / \mathbf{P} \\
\text { (no) }\end{array}$} & \multirow{2}{*}{$\begin{array}{c}\text { N/ha } \\
\text { (no) }\end{array}$} & \multirow{2}{*}{$\begin{array}{r}\text { C/P } \\
(\mathbf{k g})\end{array}$} & \multirow{2}{*}{$\begin{array}{l}\text { C/ha } \\
\text { (kg) }\end{array}$} \\
\hline & & & Husk & Shell & Meat & Water & Copra & & & & & \\
\hline \multirow{2}{*}{$\begin{array}{l}\text { LAGT x } \\
\text { TAGT }\end{array}$} & Total & $3,534.3$ & 872.8 & 637.1 & $1,266.9$ & 757.5 & 749.7 & \multirow{2}{*}{0.46} & 94.2 & 12,717 & 22.6 & 3.0 \\
\hline & Mean & $1,178.1$ & 290.9 & 212.4 & 422.3 & 252.5 & 249.9 & & 31.4 & 4,239 & 7.5 & 1.0 \\
\hline \multirow{2}{*}{$\begin{array}{l}\text { RIT x } \\
\text { BAYT }\end{array}$} & Total & $3,784.9$ & 963.8 & 628.7 & $1,376.6$ & 815.7 & 816.8 & \multirow{2}{*}{0.46} & 70.2 & 9,479 & 18.8 & 2.5 \\
\hline & Mean & $1,261.6$ & 321.3 & 209.6 & 458.9 & 271.9 & 272.3 & & 23.4 & 3,160 & 6.3 & 0.8 \\
\hline \multirow{2}{*}{$\begin{array}{l}\text { LAGT x } \\
\text { BAYT }\end{array}$} & Total & $3,670.6$ & $1,004.0$ & 580.5 & $1,265.7$ & 820.4 & 760.8 & \multirow{2}{*}{0.44} & 95.7 & 12,923 & 23.3 & 3.2 \\
\hline & Mean & $1,223.5$ & 334.7 & 193.5 & 421.9 & 273.5 & 253.6 & & 31.9 & 4,308 & 7.8 & 1.1 \\
\hline \multirow{2}{*}{$\begin{array}{l}\text { LAGT x } \\
\text { BAOT }\end{array}$} & Total & $3,821.2$ & $1,043.3$ & 624.1 & $1,293.1$ & 860.7 & 795.3 & \multirow{2}{*}{0.43} & 83.3 & 11,252 & 21.3 & 2.9 \\
\hline & Mean & $1,273.7$ & 347.8 & 208.0 & 431.0 & 286.9 & 265.1 & & 27.8 & 3,751 & 7.1 & 1.0 \\
\hline \multirow{2}{*}{$\begin{array}{l}\text { WAT x } \\
\text { RIT }\end{array}$} & Total & $3,742.4$ & $1,208.4$ & 606.7 & $1,248.4$ & 673.0 & 755.9 & \multirow{2}{*}{0.41} & 127.5 & 17,210 & 32.0 & 4.3 \\
\hline & Mean & $1,247.5$ & 402.8 & 202.2 & 416.1 & 224.3 & 252.0 & & 34.5 & 4,659 & 10.7 & 1.4 \\
\hline \multirow{2}{*}{$\begin{array}{l}\text { WAT } x \\
\text { LAGT }\end{array}$} & Total & $3,381.7$ & $1,142.7$ & 567.7 & $1,103.8$ & 567.5 & 679.4 & \multirow{2}{*}{0.39} & 132.4 & 17,869 & 29.5 & 4.0 \\
\hline & Mean & $1,127.2$ & 380.9 & 189.2 & 367.9 & 189.2 & 226.5 & & 37.8 & 5,956 & 9.8 & 1.3 \\
\hline \multirow{2}{*}{$\begin{array}{l}\text { BAOT } x \\
\text { BAYT }\end{array}$} & Total & $4,045.8$ & $1,042.4$ & 633.7 & $1,451.6$ & 918.2 & 685.9 & \multirow{2}{*}{0.46} & 100.0 & 13,500 & 30.0 & 4.1 \\
\hline & Mean & $1,348.6$ & 347.5 & 211.2 & 483.9 & 306.1 & 288.6 & & 33.3 & 4,500 & 10.0 & 1.4 \\
\hline \multirow{2}{*}{$\begin{array}{l}\text { BAOT } x \\
\text { RIT }\end{array}$} & Total & $4,970.7$ & $1,187.7$ & 760.7 & $1,662.0$ & $1,360.2$ & 941.7 & \multirow{2}{*}{0.46} & 78.3 & 10,574 & 23.9 & 3.2 \\
\hline & Mean & $1,656.9$ & 395.9 & 253.6 & 554.0 & 453.4 & 313.9 & & 19.8 & 2,677 & 8.0 & 1.1 \\
\hline \multirow{2}{*}{$\begin{array}{l}\text { BAOT } x \\
\text { WAT }\end{array}$} & Total & $3,848.3$ & $1,192.7$ & 627.2 & $1,284.4$ & 744.2 & 795.8 & \multirow{2}{*}{0.41} & 128.1 & 17,292 & 33.4 & 4.5 \\
\hline & Mean & $1,282.8$ & 397.6 & 209.1 & 428.1 & 248.1 & 265.3 & & 33.0 & 4,458 & 11.1 & 1.5 \\
\hline \multirow{2}{*}{$\begin{array}{l}\text { WAT } \mathrm{x} \\
\text { TAGT }\end{array}$} & Total & $3,710.9$ & $1,232.7$ & 650.2 & $1,194.4$ & 633.6 & 755.0 & 030 & 133.8 & 18,063 & 33.1 & 4.5 \\
\hline & Mean & $1,237.0$ & 410.9 & 216.7 & 398.1 & 211.2 & 251.7 & 0.3 & 33.9 & 4,583 & 11.0 & 1.5 \\
\hline RIT $x$ & Total & $4,952.5$ & $1,169.3$ & 736.6 & $1,709.0$ & $1,337.5$ & 927.8 & 047 & 84.1 & 11,350 & 25.3 & 3.4 \\
\hline TAGT & Mean & $1,650.8$ & 389.8 & 245.5 & 569.7 & 445.8 & 309.3 & 0.47 & 28.0 & 3,783 & 8.4 & 1.1 \\
\hline WAT $\mathrm{x}$ & Total & $3,441.4$ & $1,169.2$ & 566.0 & $1,157.4$ & 547.8 & 730.0 & 04 & 130.0 & 17,554 & 31.0 & 4.2 \\
\hline BAYT & Mean & $1,147.1$ & 389.7 & 188.7 & 386.1 & 182.6 & 243.3 & 0.40 & 33.0 & 4,456 & 10.3 & 1.4 \\
\hline LAGT $x$ & Total & $4,102.2$ & 999.4 & 636.0 & $1,445.7$ & $1,021.2$ & 842.6 & & 93.3 & 12,598 & 25.5 & 3.4 \\
\hline RIT & Mean & $1,367.4$ & 333.1 & 212.0 & 481.9 & 340.4 & 280.9 & 0.46 & 31.1 & 4,199 & 8.5 & 1.1 \\
\hline BAOT $x$ & Total & $4,144.8$ & $1,065.5$ & 701.1 & $1,387.6$ & 990.5 & 842.7 & & 96.6 & 13,035 & 27.8 & 3.7 \\
\hline TAGT & Mean & $1,381.6$ & 355.2 & 233.7 & 462.5 & 330.2 & 280.9 & 0.44 & 32.2 & 4,345 & 9.3 & 1.2 \\
\hline BAYT $x$ & Total & $3,924.7$ & 983.5 & 630.4 & $1,380.5$ & 930.3 & 842.5 & & 134.1 & 18,097 & 38.7 & 5.2 \\
\hline TAGT & Mean & $1,308.2$ & 327.8 & 210.1 & 460.2 & 310.1 & 280.8 & 0.45 & 44.7 & 6,032 & 12.9 & 1.7 \\
\hline
\end{tabular}

$\mathrm{FQV}=$ Fruit quality value $=($ weight of fresh meat $/$ weight of husk + shell + meat $)$

$\mathrm{N} / \mathrm{P}=$ Nut per palm; $\mathrm{N} / \mathrm{ha}=$ nuts per hectare $\mathrm{C} / \mathrm{P}=$ Copra per palm; $\mathrm{C} / \mathrm{ha}=$ Copra per hectare 
Appendix 2. Coconut seednuts processed and distributed, 2000-2005

\begin{tabular}{|c|r|r|r|r|r|r|r|r|r|r|r|r|r|}
\hline \multirow{2}{*}{ Year } & \multicolumn{10}{|c|}{ PCA Region } & \multicolumn{1}{|c|}{ Total } \\
\cline { 2 - 13 } & I-IV B & I-IV A & V & VI & VII & VIII & IX & X & XI & XII & XIII & ARMM & \\
\hline 2000 & 10,150 & 8,700 & & & 8,100 & & & & 13,140 & 3,450 & & & 43,540 \\
2001 & 22,125 & 1,950 & & 15,380 & & & & & 435 & & 5,000 & 1,400 & 46,290 \\
2002 & 38,485 & & & 10,000 & 14,165 & & & 15,000 & & 5,080 & & 1,700 & 84,430 \\
2003 & 17,012 & 2,000 & & 2,574 & 2,040 & 13,006 & 4,306 & & & 1,730 & & & 42,668 \\
2004 & 26,983 & 1,000 & 1,770 & 2,915 & & & 10,480 & 3,600 & 2,196 & & & & 48,944 \\
2005 & 13,929 & 11,130 & & 300 & & & 25,431 & 100 & & & & 2,050 & 52,940 \\
\hline TOTAL & 128,684 & 24,780 & 1,770 & 31,169 & 24,305 & 13,006 & 40,217 & 18,700 & 15,771 & 10,260 & 5,000 & 5,150 & 318,812 \\
\hline \hline
\end{tabular}

Appendix 3. Coconut seedlings selected and distributed, 2001-2005

\begin{tabular}{|c|c|c|c|c|c|c|c|c|c|c|c|}
\hline \multirow[b]{2}{*}{ Year } & \multicolumn{5}{|c|}{ PCA Region IX } & \multirow[b]{2}{*}{ Subtotal } & \multicolumn{3}{|c|}{ Other Provinces } & \multirow[b]{2}{*}{ Subtotal } & \multirow[b]{2}{*}{ Total } \\
\hline & Z City & $\begin{array}{c}\mathrm{Z} \\
\text { Sibugay }\end{array}$ & $\begin{array}{c}\mathrm{Z} \\
\text { Norte }\end{array}$ & Z Sur & Basilan & & $\begin{array}{l}\text { Lanao } \\
\text { Norte }\end{array}$ & Davao & Manila & & \\
\hline 2001 & 1,301 & 3,121 & & 230 & 74 & 4,726 & & & 9 & 9 & 4,735 \\
\hline 2002 & 9,681 & 1,035 & 1,908 & 1,680 & 200 & 14,504 & & & & 0 & 14,504 \\
\hline 2003 & 3,709 & 2,071 & 5,101 & 286 & 1,502 & 12,669 & & & 2 & 2 & 12,671 \\
\hline 2004 & 3,494 & 530 & 3,848 & 4,800 & 14 & 12,686 & 30 & 5 & & 35 & 12,721 \\
\hline 2005 & 2,845 & 1,050 & 1,050 & 5,335 & 1,000 & 11,280 & & 50 & 12 & 62 & 11,342 \\
\hline TOTAL & 21,030 & 7,807 & 11,907 & 12,331 & 2,790 & 55,865 & 30 & 55 & 23 & 108 & 55,973 \\
\hline
\end{tabular}


Appendix 4. Number of nuts and copra yield of PCA SYN VAR 001 parental base population, 1997-2004

\begin{tabular}{|c|c|c|c|c|}
\hline $\begin{array}{l}\text { VARIETY/ } \\
\text { YEAR }\end{array}$ & $\begin{array}{l}\mathbf{N} / \mathbf{P} \\
\text { (no.) }\end{array}$ & $\begin{array}{c}\text { N/HA } \\
\text { (no.) }\end{array}$ & $\begin{array}{l}\mathbf{C} / \mathbf{P} \\
(\mathbf{k g})\end{array}$ & $\begin{array}{l}\text { C/HA } \\
\text { (tons) }\end{array}$ \\
\hline \multicolumn{5}{|c|}{ BAOT x BAYT } \\
\hline 1997 & 38 & 5,184 & 13.1 & 1.8 \\
\hline 1998 & 32 & 4,311 & 7.8 & 1.1 \\
\hline 1999 & 17 & 2,253 & 4.7 & 0.6 \\
\hline 2000 & 59 & 7,930 & 22.4 & 3.0 \\
\hline 2001 & 40 & 5,418 & 16.1 & 2.2 \\
\hline 2002 & 57 & 7,733 & 23.7 & 3.2 \\
\hline 2003 & 45 & 6,134 & 15.6 & 2.1 \\
\hline 2004 & 60 & 8,150 & 17.9 & 2.4 \\
\hline TOTAL & 349 & 47,113 & 121.4 & 16.4 \\
\hline Mean & 44 & 5,889 & 15.2 & 2.1 \\
\hline \multicolumn{5}{|l|}{ BAOT $x$ RIT } \\
\hline 1997 & 41 & 5,467 & 14.0 & 1.9 \\
\hline 1998 & 33 & 4,477 & 8.4 & 1.1 \\
\hline 1999 & 9 & 1,274 & 3.3 & 0.4 \\
\hline 2000 & 73 & 9,800 & 29.8 & 4.0 \\
\hline 2001 & 41 & 5,480 & 16.2 & 2.2 \\
\hline 2002 & 55 & 7,369 & 22.6 & 3.0 \\
\hline 2003 & 46 & 6,156 & 16.4 & 2.2 \\
\hline 2004 & 47 & 6,395 & 18.4 & 2.5 \\
\hline TOTAL & 344 & 46,418 & 129.1 & 17.3 \\
\hline Mean & 43 & 5,802 & 16.1 & 2.2 \\
\hline \multicolumn{5}{|c|}{ BAOT x TAGT } \\
\hline 1997 & 14 & 1,868 & 4.5 & 0.6 \\
\hline 1998 & 36 & 4,910 & 8.9 & 1.2 \\
\hline 1999 & 14 & 1,839 & 3.7 & 0.5 \\
\hline 2000 & 66 & 8,917 & 26.4 & 3.6 \\
\hline 2001 & 43 & 5,859 & 18.7 & 2.5 \\
\hline 2002 & 63 & 8,533 & 28.0 & 3.8 \\
\hline 2003 & 46 & 6,215 & 16.2 & 2.2 \\
\hline 2004 & 64 & 8,663 & 23.5 & 3.2 \\
\hline TOTAL & 347 & 46,804 & 129.9 & 17.6 \\
\hline Mean & 43 & 5,850 & 16.2 & 2.2 \\
\hline \multicolumn{5}{|c|}{ BAOT x WAT } \\
\hline 1997 & 54 & 7,220 & 16.3 & 2.2 \\
\hline 1998 & 52 & 7,046 & 10.9 & 1.5 \\
\hline 1999 & 29 & 3,926 & 8.2 & 1.1 \\
\hline 2000 & 90 & 12,136 & 30.1 & 4.1 \\
\hline 2001 & 59 & 7,998 & 20.1 & 2.7 \\
\hline 2002 & 80 & 10,807 & 27.3 & 3.7 \\
\hline 2003 & 69 & 9,351 & 20.9 & 2.8 \\
\hline 2004 & 78 & 10,458 & 21.6 & 2.9 \\
\hline TOTAL & 512 & 68,942 & 155.4 & 21.0 \\
\hline Mean & 64 & 8,618 & 19.4 & 2.6 \\
\hline
\end{tabular}

\begin{tabular}{|c|c|c|c|c|}
\hline $\begin{array}{l}\text { VARIETY/ } \\
\text { YEAR }\end{array}$ & $\begin{array}{l}\text { N/P } \\
\text { (no.) }\end{array}$ & $\begin{array}{c}\text { N/HA } \\
\text { (no.) }\end{array}$ & $\begin{array}{l}\text { C/P } \\
(\mathrm{kg})\end{array}$ & $\begin{array}{l}\text { C/HA } \\
\text { (tons) }\end{array}$ \\
\hline \multicolumn{5}{|c|}{ BAYT x TAGT } \\
\hline 1997 & 24 & 3,178 & 7.6 & 1.0 \\
\hline 1998 & 39 & 5,223 & 8.4 & 1.1 \\
\hline 1999 & 28 & 3,797 & 8.4 & 1.1 \\
\hline 2000 & 73 & 9,894 & 26.0 & 3.5 \\
\hline 2001 & 46 & 6,235 & 16.2 & 2.2 \\
\hline 2002 & 60 & 8,151 & 22.5 & 3.0 \\
\hline 2003 & 49 & 6,588 & 15.6 & 2.1 \\
\hline 2004 & 60 & 8,109 & 17.2 & 2.3 \\
\hline TOTAL & 379 & 51,175 & 121.9 & 16.3 \\
\hline Mean & 47 & 6,397 & 15.2 & 2.0 \\
\hline \multicolumn{5}{|c|}{ LAGT x BAOT } \\
\hline 1997 & 30 & 4,087 & 8.9 & 1.2 \\
\hline 1998 & 42 & 5,717 & 9.5 & 1.3 \\
\hline 1999 & 18 & 2,412 & 5.0 & 0.7 \\
\hline 2000 & 70 & 9,486 & 24.9 & 3.4 \\
\hline 2001 & 49 & 6,631 & 18.0 & 2.4 \\
\hline 2002 & 64 & 8,641 & 23.8 & 3.2 \\
\hline 2003 & 60 & 8,145 & 19.0 & 2.6 \\
\hline 2004 & 73 & 9,914 & 22.2 & 3.0 \\
\hline TOTAL & 406 & 55,033 & 131.2 & 17.8 \\
\hline Mean & 51 & 6,879 & 16.4 & 2.2 \\
\hline \multicolumn{5}{|c|}{ LAGT x BAYT } \\
\hline 1997 & 32 & 4,363 & 9.6 & 1.3 \\
\hline 1998 & 46 & 6,205 & 9.5 & 1.3 \\
\hline 1999 & 24 & 3,235 & 6.1 & 0.8 \\
\hline 2000 & 68 & 9,210 & 22.9 & 3.1 \\
\hline 2001 & 40 & 5,377 & 14.4 & 1.9 \\
\hline 2002 & 53 & 7,167 & 18.7 & 2.5 \\
\hline 2003 & 49 & 6,656 & 14.9 & 2.0 \\
\hline 2004 & 64 & 8,568 & 18.5 & 2.5 \\
\hline TOTAL & 376 & 50,781 & 114.6 & 15.5 \\
\hline Mean & 47 & 6,348 & 14.3 & 1.9 \\
\hline \multicolumn{5}{|l|}{ LAGT x RIT } \\
\hline 1997 & 38 & 5,181 & 11.8 & 1.6 \\
\hline 1998 & 40 & 5,402 & 9.2 & 1.2 \\
\hline 1999 & 19 & 2,522 & 5.7 & 0.8 \\
\hline 2000 & 88 & 11,887 & 35.2 & 4.8 \\
\hline 2001 & 42 & 5,686 & 15.5 & 2.1 \\
\hline 2002 & 63 & 8,503 & 23.5 & 3.2 \\
\hline 2003 & 42 & 5,630 & 13.8 & 1.9 \\
\hline 2004 & 54 & 7,281 & 17.0 & 2.3 \\
\hline TOTAL & 386 & 52,092 & 131.7 & 17.8 \\
\hline Mean & 48 & 6,511 & 16.5 & 2.2 \\
\hline
\end{tabular}

Appendix Table 4. Continued.. 
Cord 2008, 24 (1)

\begin{tabular}{|c|c|c|c|c|c|c|c|c|c|}
\hline $\begin{array}{l}\text { VARIETY/ } \\
\text { YEAR }\end{array}$ & $\begin{array}{l}\text { N/P } \\
\text { (no.) }\end{array}$ & $\begin{array}{c}\text { N/HA } \\
\text { (no.) }\end{array}$ & $\begin{array}{l}\mathrm{C} / \mathrm{P} \\
(\mathrm{kg})\end{array}$ & $\begin{array}{l}\text { C/HA } \\
\text { (tons) }\end{array}$ & $\begin{array}{l}\text { VARIETY/ } \\
\text { YEAR }\end{array}$ & $\begin{array}{l}\text { N/P } \\
\text { (no.) }\end{array}$ & $\begin{array}{c}\text { N/HA } \\
\text { (no.) }\end{array}$ & $\begin{array}{l}\mathrm{C} / \mathrm{P} \\
(\mathrm{kg})\end{array}$ & $\begin{array}{l}\text { C/HA } \\
\text { (tons) }\end{array}$ \\
\hline $\begin{array}{l}\text { LAGT } \mathrm{x} \\
\text { TAGT }\end{array}$ & & & & & $\begin{array}{l}\text { WAT x } \\
\text { BAYT }\end{array}$ & & & & \\
\hline 1997 & 30 & 4,005 & 8.1 & 1.1 & 1997 & 48 & 6,451 & 13.0 & 1.8 \\
\hline 1998 & 47 & 6,348 & 9.8 & 1.3 & 1998 & 55 & 7,419 & 11.0 & 1.5 \\
\hline 1999 & 19 & 2,607 & 5.2 & 0.7 & 1999 & 35 & 4,685 & 8.9 & 1.2 \\
\hline 2000 & 76 & 10,214 & 27.1 & 3.7 & 2000 & 88 & 11,837 & 31.0 & 4.2 \\
\hline 2001 & 47 & 6,276 & 17.3 & 2.3 & 2001 & 68 & 9,126 & 21.0 & 2.8 \\
\hline 2002 & 68 & 9,142 & 26.7 & 3.6 & 2002 & 94 & 12,714 & 26.4 & 3.6 \\
\hline 2003 & 60 & 8,042 & 18.6 & 2.5 & 2003 & 85 & 11,444 & 23.7 & 3.2 \\
\hline 2004 & 76 & 10,256 & 22.4 & 3.0 & 2004 & 100 & 13,451 & 24.8 & 3.4 \\
\hline TOTAL & 422 & 56,890 & 135.3 & 18.3 & TOTAL & 573 & 77,127 & 159.8 & 21.7 \\
\hline Mean & 53 & 7,111 & 16.9 & 2.3 & Mean & 72 & 9,641 & 20.0 & 2.7 \\
\hline LAGT $x$ WAT & & & & & WAT x RIT & & & & \\
\hline 1997 & 53 & 7,191 & 13.5 & 1.8 & 1997 & 59 & 7,893 & 16.3 & 2.2 \\
\hline 1998 & 56 & 7,600 & 10.7 & 1.4 & 1998 & 47 & 6,303 & 9.9 & 1.3 \\
\hline 1999 & 31 & 4,122 & 7.2 & 1.0 & 1999 & 28 & 3,818 & 7.5 & 1.0 \\
\hline 2000 & 96 & 12,992 & 26.0 & 3.5 & 2000 & 103 & 13,942 & 34.6 & 4.7 \\
\hline 2001 & 73 & 9,873 & 21.4 & 2.9 & 2001 & 63 & 8,453 & 20.2 & 2.7 \\
\hline 2002 & 101 & 13,570 & 29.3 & 4.0 & 2002 & 89 & 11,949 & 28.4 & 3.8 \\
\hline 2003 & 94 & 12,623 & 23.9 & 3.2 & 2003 & 70 & 9,491 & 20.3 & 2.7 \\
\hline 2004 & 105 & 14,153 & 24.8 & 3.4 & 2004 & 73 & 9,806 & 20.1 & 2.7 \\
\hline TOTAL & 608 & 82,124 & 156.8 & 21.1 & TOTAL & 531 & 71,655 & 157.4 & 21.2 \\
\hline Mean & 76 & 10,265 & 19.6 & 2.6 & Mean & 66 & 8,957 & 19.7 & 2.7 \\
\hline RIT x BAYT & & & & & $\begin{array}{l}\text { WAT } \mathrm{x} \\
\text { TAGT }\end{array}$ & & & & \\
\hline 1997 & 32 & 4,356 & 10.4 & 1.4 & 1997 & 51 & 6,935 & 14.8 & 2.0 \\
\hline 1998 & 35 & 4,751 & 7.9 & 1.1 & 1998 & 56 & 7,496 & 11.6 & 1.6 \\
\hline 1999 & 9 & 1,216 & 2.4 & 0.3 & 1999 & 35 & 4,664 & 8.9 & 1.2 \\
\hline 2000 & 71 & 9,582 & 26.9 & 3.6 & 2000 & 102 & 13,727 & 32.3 & 4.4 \\
\hline 2001 & 53 & 7,109 & 20.3 & 2.7 & 2001 & 71 & 9,633 & 24.1 & 3.3 \\
\hline 2002 & 69 & 9,258 & 25.2 & 3.4 & 2002 & 97 & 13,090 & 30.2 & 4.1 \\
\hline 2003 & 46 & 6,161 & 14.8 & 2.0 & 2003 & 84 & 11,318 & 24.1 & 3.2 \\
\hline 2004 & 64 & 8,577 & 19.4 & 2.6 & 2004 & 102 & 13,739 & 28.4 & 3.8 \\
\hline TOTAL & 378 & 51,010 & 127.3 & 17.2 & TOTAL & 598 & 80,602 & 174.4 & 23.6 \\
\hline Mean & 47 & 6,376 & 15.9 & 2.1 & Mean & 75 & 10,075 & 21.8 & 3.0 \\
\hline RIT x TAGT & & & & & Grand Mean & 55 & 7,400 & 17.4 & 2.4 \\
\hline 1997 & 39 & 5,267 & 13.0 & 1.8 & & & & & \\
\hline 1998 & 34 & 4,637 & 8.5 & 1.2 & & & & & \\
\hline 1999 & 18 & 2,391 & 6.1 & 0.8 & & & & & \\
\hline 2000 & 77 & 10,375 & 33.7 & 4.5 & & & & & \\
\hline 2001 & 49 & 6,564 & 20.6 & 2.8 & & & & & \\
\hline 2002 & 58 & 7,866 & 25.7 & 3.5 & & & & & \\
\hline 2003 & 43 & 5,832 & 16.1 & 2.2 & & & & & \\
\hline 2004 & 55 & 7,362 & 19.4 & 2.6 & & & & & \\
\hline TOTAL & 373 & 50,294 & 143.0 & 19.3 & & & & & \\
\hline Mean & 47 & 6,287 & 17.9 & 2.4 & & & & & \\
\hline
\end{tabular}

